
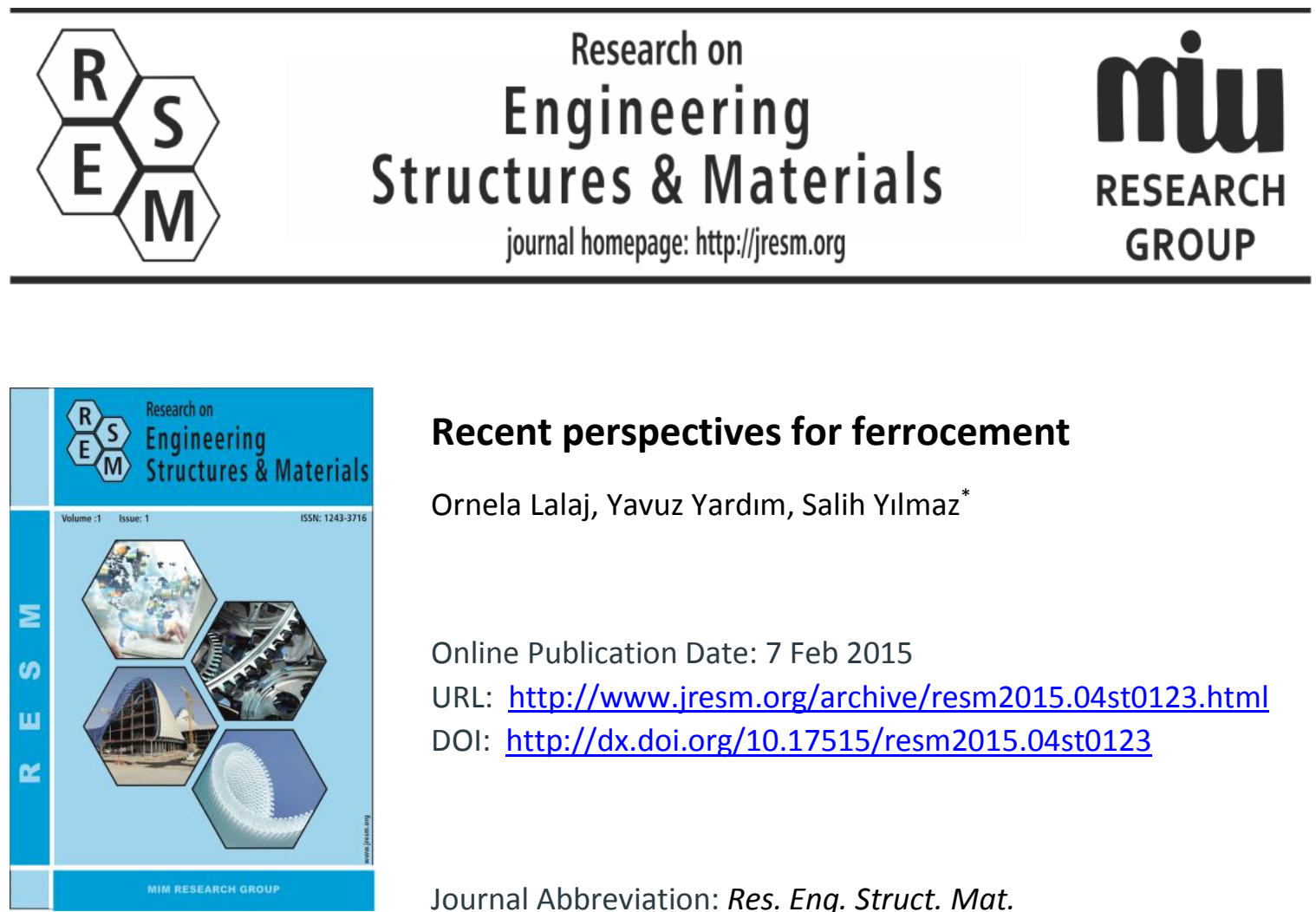

\title{
Recent perspectives for ferrocement
}

Ornela Lalaj, Yavuz Yardım, Salih Yılmaz*

Online Publication Date: 7 Feb 2015

URL: http://www.jresm.org/archive/resm2015.04st0123.html

DOI: http://dx.doi.org/10.17515/resm2015.04st0123

Journal Abbreviation: Res. Eng. Struct. Mat.

\section{To cite this article}

Lalaj O, Yardım Y, Yılmaz S. Recent perspectives for ferrocement. Res. Eng. Struct. Mat., 2015; 1: 11-23.

\section{Disclaimer}

All the opinions and statements expressed in the papers are on the responsibility of author(s) and are not to be regarded as those of the journal of Research on Engineering Structures and Materials (RESM) organization or related parties. The publishers make no warranty, explicit or implied, or make any representation with respect to the contents of any article will be complete or accurate or up to date. The accuracy of any instructions, equations, or other information should be independently verified. The publisher and related parties shall not be liable for any loss, actions, claims, proceedings, demand or costs or damages whatsoever or howsoever caused arising directly or indirectly in connection with use of the information given in the journal or related means. 


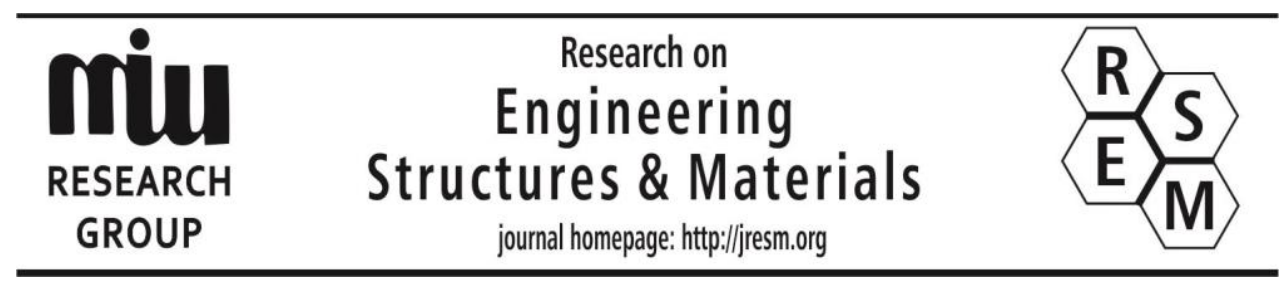

Review Article

\title{
Recent perspectives for ferrocement
}

\author{
Ornela Lalaj ${ }^{1}$, Yavuz Yardım², Salih Yılmaz ${ }^{* 1}$ \\ ${ }^{1}$ Izmir Katip Çelebi University, Department of Civil Engineering, Turkey \\ ${ }^{2}$ Epoka University, Department of Civil Engineering, Albania
}

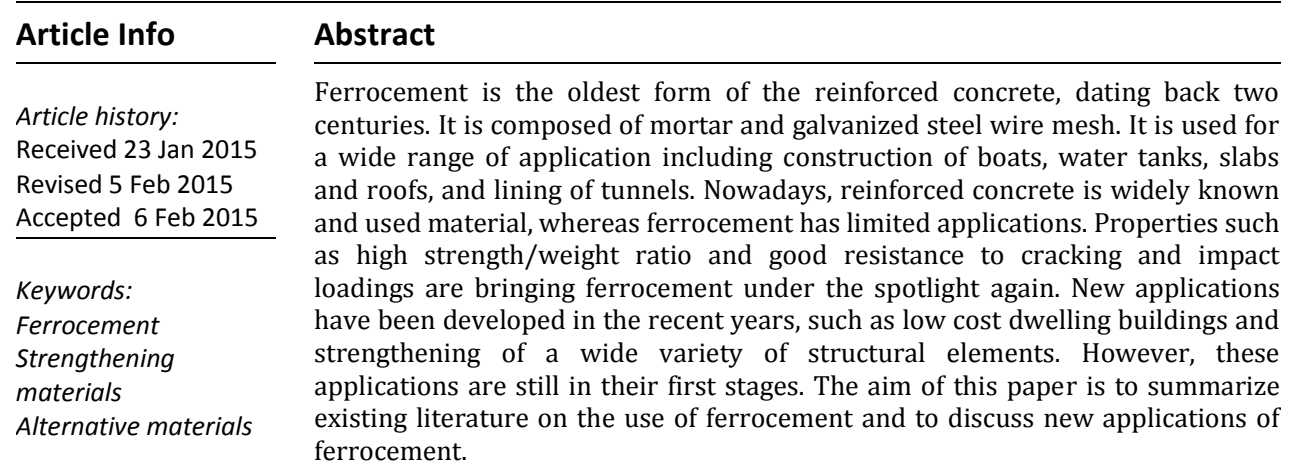

(C) 2015 MIM Research Group. All rights reserved.

\section{Introduction}

Ferrocement is the first known form of reinforced concrete which was first used two centuries ago in Italy and France, mainly for construction of boats. It is made of mortar and steel wire mesh and usually it is cast in very thin sections, thus making it possible to give any desired shape, as shown in Figure 1. Typical section thickness for ferrocement is 2-3 cm. Ferrocement is an interesting and versatile material, which has not been extensively studied, and offers many new areas for research and new applications. It is a composite material, composed of steel wire mesh and mortar matrix. Different types of meshes can be used to produce ferrocement sheets, depending on the application requirements. The State-of-the-art report on ferrocement, from ACI [1] distinguishes ferrocement from conventional concrete especially when comparing the behavior in tension and flexure of the two materials. The tensile and flexural strength of ferrocement are attributed to the wire mesh, as the mortar matrix cracks at early loading stages. Compression behavior is similar to that of conventional concrete. Good properties of this material comprise the cracking behavior, impact behavior and load-deformation behavior. Due to good distribution of reinforcement, ferrocement can control crack development, though minor cracks will be present in the matrix, even before loading. These minor cracks can develop due to inadequate curing or cover thickness. Durability and fire resistance are not very high, mostly owning to the thin sections in which ferrocement is casted. 
The main types of mesh used in ferrocement application are hexagonal mesh, woven mesh, welded mesh and expanded metal, shown in Figure 2. In general, it can be stated that the properties of the ferrocement are greatly affected by the type and the orientation of the reinforcement used. The best performance, for almost all properties is obtained from the welded mesh, which has two strong directions that are equally reinforced. This type of mesh is weaker in $45^{\circ}$ direction, but still gives better results when compared to expanded metal (unidirectional mesh), woven or hexagonal mesh.

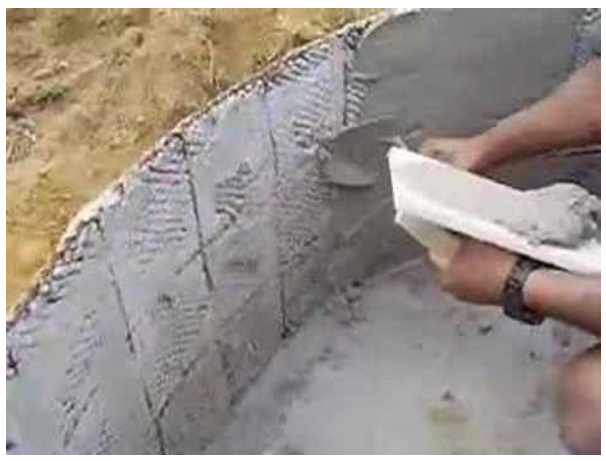

Fig. 1 Ferrocement and its constituents, mortar and steel, being given a cylindrical shape

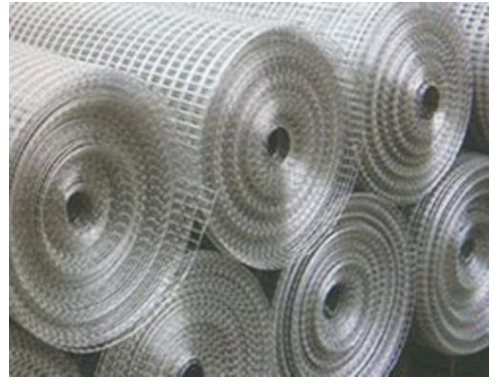

(a)

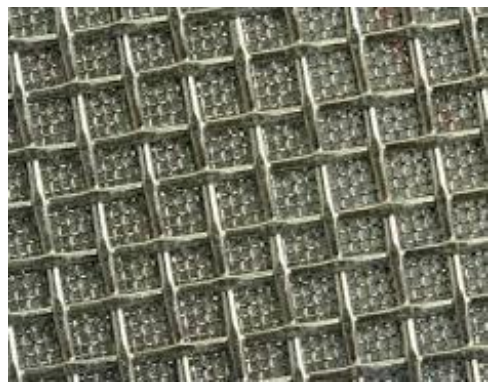

(c)

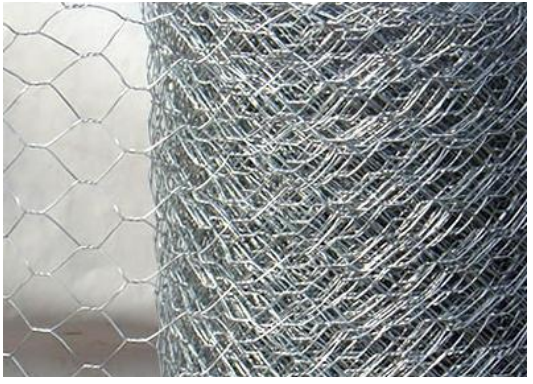

(b)

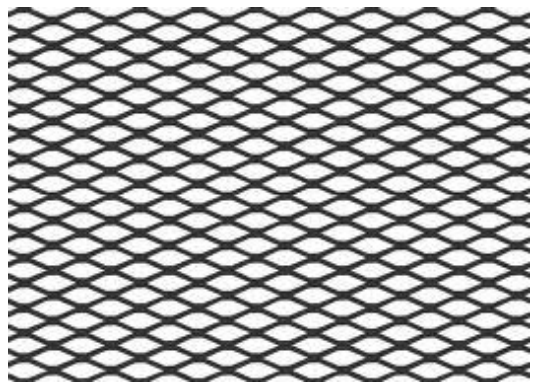

(d)

Fig. 2 Types of wire mesh used in ferrocement applications; (a) welded wire mesh; (b) hexagonal wire mesh; (c) woven wire mesh; (d) expanded metal

A comparative study between plain mortar specimens and ferrocement specimens subjected to various types of tests has been conducted by Arif et al.[2]. This study has set up the path to quantify the effect of wire mesh in different mechanical properties of 
ferrocement. In this study it has been once more affirmed that the orientation of the wire meshes affects the behavior of the ferrocement. In general, the addition of wire meshes changes the behavior of mortars. For instance, ferrocement loaded in uniaxial tension fails gradually. At first the mortar cracks, afterwards, the load is almost all transferred to the wire meshes and ultimate failure comes with the yield of the steel, unlike plain mortar, which fails in brittle manner, with a single crack along the midsection. Wire meshes contribute also to the compressive strength of mortar. After the mortar is cracked and spalled, the wire mesh buckles and then the specimen fails. It is curious that the elastic modulus is higher in compression than in tension for ferrocement, and this is attributed to the greater stiffness of mortar in compression. The flexural behavior of ferrocement specimens is similar to the flexural behavior of beams. The strength is increased by increasing the number of wire meshes.

The original use of ferrocement is the construction of mediums size boats, though other usages related to the agricultural applications have emerged with time. In this paper two applications will be exploited: the use of ferrocement for the construction of low-cost houses and for strengthening of structural elements.

\section{Low-Cost Dwelling Houses}

It is often said that ferrocement is widely used for low-rise, low-cost, earthquake resistant houses. Ferrocement structures have been used for housing or public buildings for 15 years in Chile as reported by Chapple [3] shown in Figure 4 (a), 4 (b), 20 years in Mexico as reported by Montes [4] and 25 years in Columbia, reported by Ruiz et al.[5] shown in Figure 3. The good properties ferrocement possesses, such as high tensile strength/weight ratio, unskilled work required, light roofing which generates less dead loads and does not cause damage in case of failure, make it an interesting solution for housing, as reported by Saleem et al. [6]. In the cited study, a small ferrocement house is modeled and analyzed under seismic loads. The analytical model indicates good earthquake resistant behavior. In Ruiz et al. [5], two ferrocement house prototypes are constructed and then tested under cyclic loading. The results of the test indicate high lateral displacement capacity, high energy absorption capacity and good resistance to earthquake loading. The presence of lateral loading, negatively affects the stiffness and resistance of such structural systems. During these tests it was observed the formation of plastic hinges in the connections structure roof, which would lead to the failure of the structure. The resistance of real ferrocement structures under earthquake loading was tested during the earthquake of Chile, in $27^{\text {th }}$ of February, 2010. About 200 houses were subjected to an earthquake of magnitude 8.8. In-situ observations from Chapple [3] and Institute of Cement and Concrete of Chile [7] showed that the structures did not suffer any damages, and performed well under seismic forces. In Figure 4 (c) is shown the construction of a ferrocement house that is earthquake resistant, as reported by Institute of Cement and Concrete of Chile [7].

\section{Strengthening of Structural Elements}

Strengthening has become a major concern over the last decades. For various reasons, including historic importance, change of occupation, natural disasters, development of new codes that provide safer design, etc., the need for strengthening existing structures is increasing. Ferrocement is considered as an attractive alternative for retrofit. Current studies have used this material for retrofit of reinforced concrete beams and columns, and reinforced concrete beam-column joints, for strengthening of masonry columns, bearing walls and infill walls. Interesting results have been obtained from these studies which suggest that ferrocement can be successfully used for strengthening structural elements, either damaged or undamaged. 


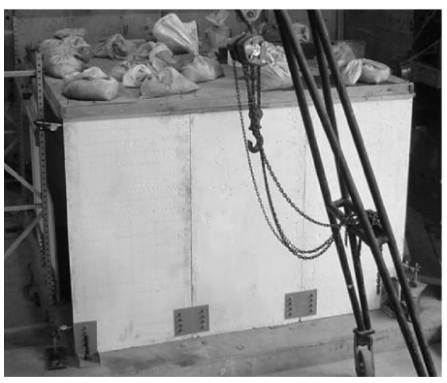

(a)

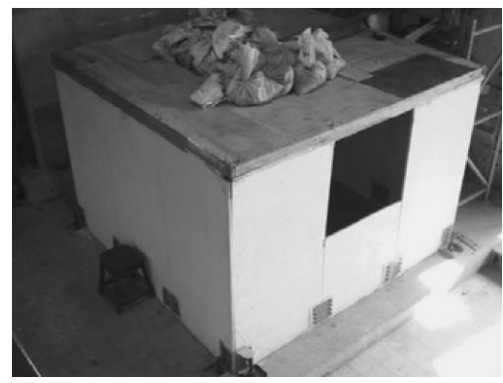

(b)

Fig. 3 Ferrocement houses tested in lateral loads in laboratory; (a) prototype I; (b) prototype II; (courtesy of Ruiz et al. [5])

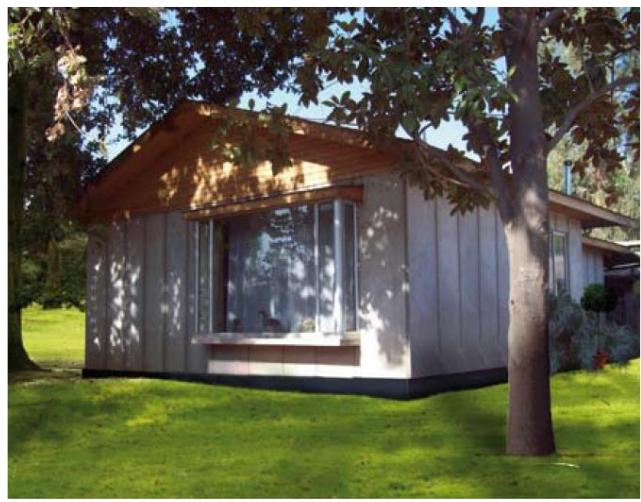

(a)

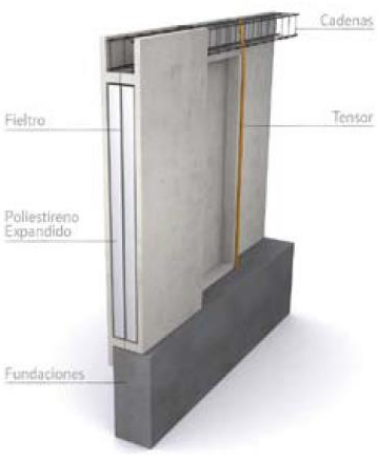

(b)

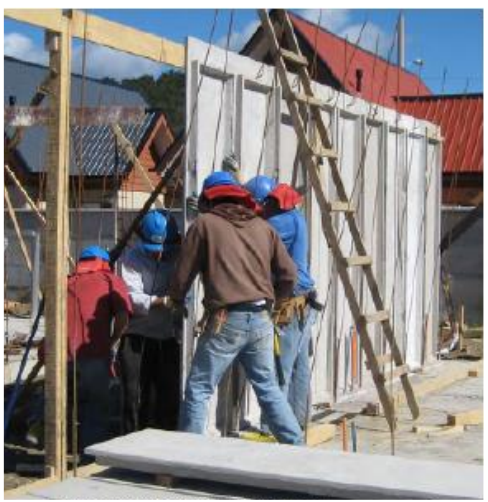

(c)

Fig. 4 Ferrocement houses (a) a ferrocement house in Chile, (courtesy of Chapple [3]); (b) the construction unit of such house; (c) another ferrocement house being constructed in Chile, (courtesy of Institute of Cement and Concrete of Chile [7]) 


\subsection{Strengthening Reinforced Concrete Elements}

Ferrocement is used for strengthening reinforced concrete columns for different types of deficiencies. Tested columns have been jacketed with ferrocement layers, in order to provide extra confinement to the section. The typical thickness of ferrocement varies between $1.5-3 \mathrm{~cm}$. Overlapping of the wire mesh is generally provided to avoid opening of the mesh reinforcement. Afterwards, the wire mesh is plastered with mortar and cured before testing. The mechanism used to increase in axial capacity of columns is to provide better confinement to the existing element. Studies by Mourad et al. [8], Kaish et al. [9], Kaish et al. [10], Kondraivendhan et al. [11] and Xiong et al. [12], (Figure 5) have indicated that this material can successfully increase strength, stiffness, ductility and cracking behavior of deficient columns. Ferrocement works as an external confinement element, thus restraining the column from lateral expansion, increasing the axial capacity and providing a more uniform stress distribution across the section. The failure mode is ductile as opposed to the brittle failure of concrete columns. Many hair-like cracks develop prior to reaching failure.
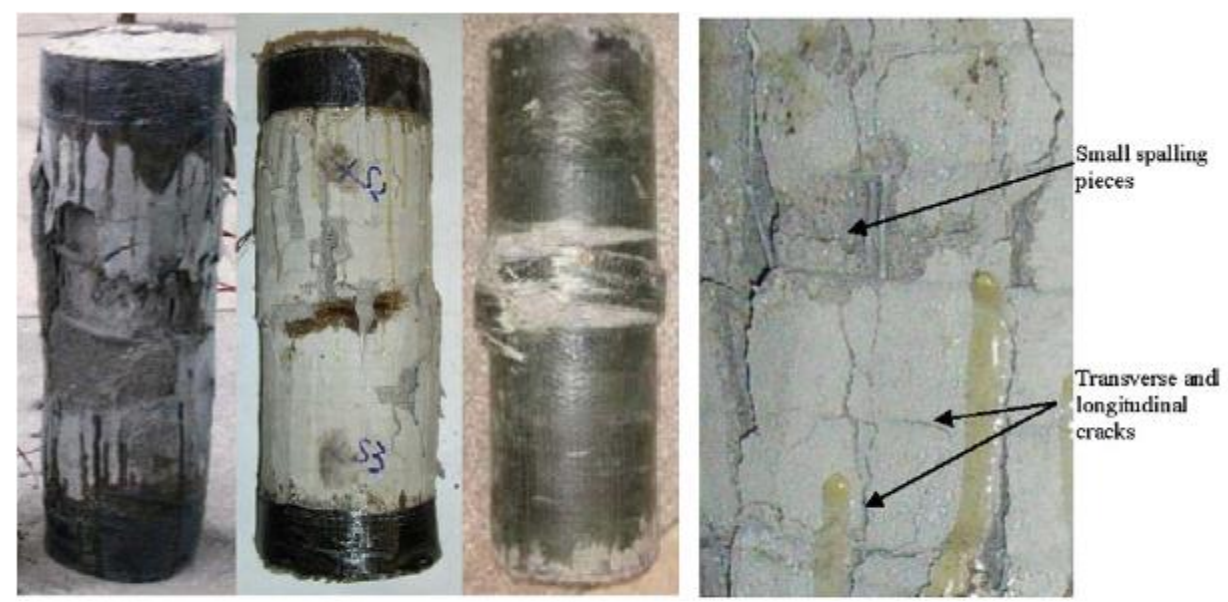

Fig. 5 Circular columns strengthened with ferrocement and FRP (courtesy of Xiong et al. [12])

The effect of varying different parameters of ferrocement jacketing has been investigated. For instance, Kondraivendhan et al. [11] investigated the effect of concrete grade; Kaish et al. [9] and Kaish et al. [10] investigated the number, type and orientation of mesh layers. The results indicate that ferrocement can increase the capacity of all existing element, with no regards on the grade of concrete. Figure 6 and 7 shows RC columns strengthened with ferrocement jacketing.

On the other hand, the behavior of strengthened columns is similar, there is shift in stress concentration from corners to mid-sides for all configurations tested. Table 1 presents the summary of these studies on columns.

In a comparative study by Xiong et al. [12] both ferrocement and fiber reinforced polymers were used to strengthen columns. Two layers of FRP were used, while the layers of wire mesh varied from 1 to 4 . Ferrocement jacketing yields greater increase in ductility and energy absorption than FRP. Mourad et al. [8] investigated the behavior of preloaded, predamaged columns wrapped with ferrocement jackets. The strength and stiffness of these columns was almost restored to original levels, while ductility did not experience same level of enhancement. 


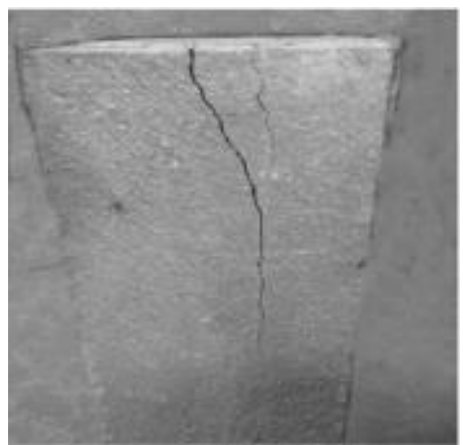

(a)

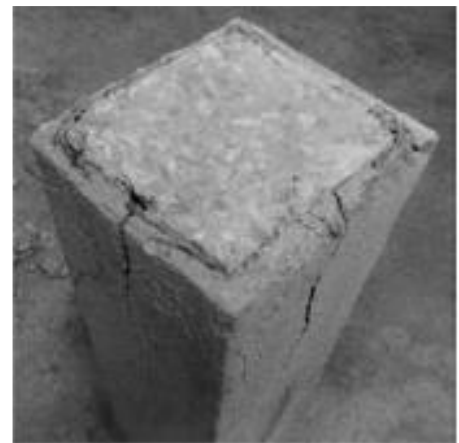

(b)

Fig. 6 Rectangular columns, strengthened with ferrocement layers, anchored with shear keys in the existing column, tested under axial load (courtesy of Kaish et al. [9])

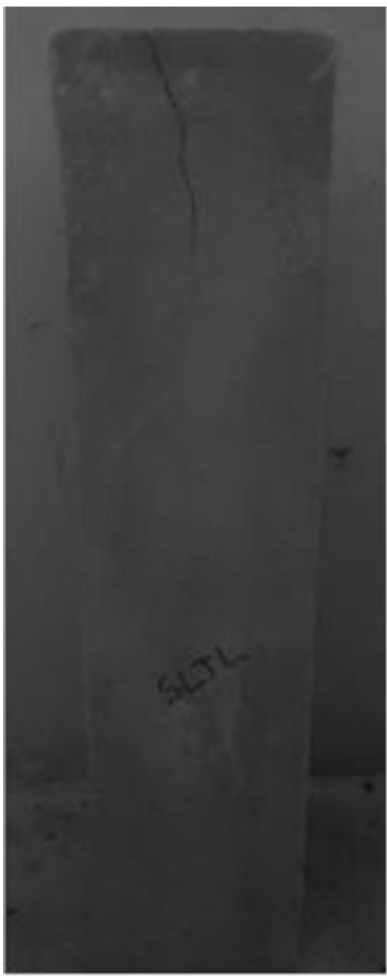

(a)

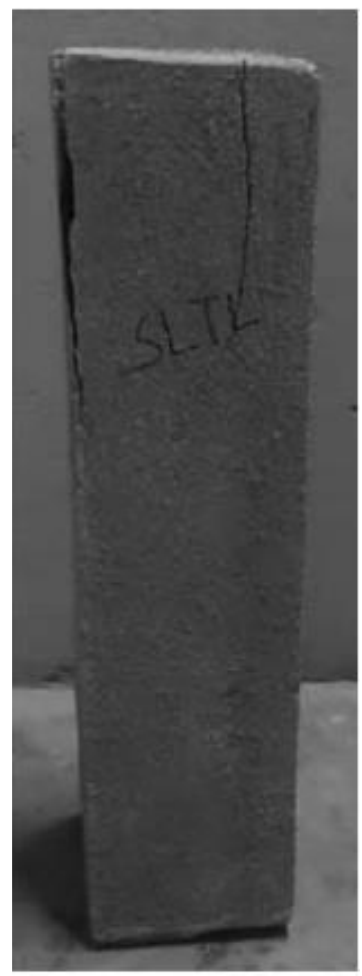

(b)

Fig. 7 Rectangular columns, strengthened with ferrocement layers, anchored with shear keys in the existing column; (a) tested under axial load; (b) tested under eccentric load; (courtesy of Kaish et al. [9])

Shear and flexural strengthening of reinforced concrete columns with ferrocement overlays yields similar results. Kazemi et al. [13] reported increase of shear strength and ductility even when the reinforcement percentage was low, while further increase in percentage of wire mesh further increased the shear capacity. Failure is ductile with fine distributed shear cracks in the jacket and large deformations taking place in the 
specimen. Tests carried out on flexural strength of columns strengthened with ferrocement by Abdullah and Takiguchi [14] indicate that flexural strength is unaffected by the addition of ferrocement jackets.

Table 1 Summary of tests and variables investigated for reinforced concrete columns

\begin{tabular}{|c|c|c|c|c|c|}
\hline $\begin{array}{c}\text { Study } \\
\text { Ref. }\end{array}$ & $\begin{array}{c}\text { Concrete } \\
\text { properties }\end{array}$ & $\begin{array}{c}\text { Mesh } \\
\text { properties }\end{array}$ & $\begin{array}{c}\text { Object } \\
\text { of study }\end{array}$ & Specimens & Findings \\
\hline [8] & $\begin{array}{l}\text { fc }=25 \mathrm{MPa} \\
\text { (for mortar) } \\
\mathrm{fc}=63 \mathrm{MPa} \\
\mathrm{ft}=5 \mathrm{MPa}\end{array}$ & $\begin{array}{l}\text { WWM - } \\
12 \times 12 \mathrm{~mm} \\
\text { fy }=385 \mathrm{MPa} \\
\varepsilon y=0.0037 \\
2 \text { layers }\end{array}$ & Axial & $\begin{array}{l}150 \times 150 \\
\mathrm{~mm} \\
\mathrm{~h}=1000 \mathrm{~mm}\end{array}$ & $\begin{array}{l}\text { - } 33 \% \text { strength increase and } \\
26 \% \text { stiffness increase for the } \\
\text { plain columns } \\
\text { - } 28 \% \text { and } 15 \% \text { strength } \\
\text { increase for columns } \\
\text { preloaded at } 60 \% \text { and } 80 \% \text { of } \\
\text { ultimate load } \\
\text { - Repairing failed columns } \\
\text { restores their strength and } \\
\text { stiffness } \\
\text { - Ductile failure for all columns } \\
\text { except for the ones repaired } \\
\text { after previously being loaded } \\
\text { to failure }\end{array}$ \\
\hline [9] & $\begin{array}{l}\mathrm{fc}=22.9- \\
24.2 \mathrm{MPa} \\
\text { (for mortar) } \\
\mathrm{fc}=37.23 \\
\mathrm{MPa}\end{array}$ & $\begin{array}{l}\text { WWM - } \\
12 \times 12 \mathrm{~mm} \\
1 \text { layer }\end{array}$ & Axial & $\begin{array}{l}100 \times 100 \\
\mathrm{~mm} \\
\mathrm{~h}=600 \mathrm{~mm}\end{array}$ & $\begin{array}{l}\text { - Improved axial load capacity } \\
\text { and deformation } \\
\text { - Best strengthening } \\
\text { configuration: SLTL (single } \\
\text { layer, with two extra layers in } \\
\text { the corners }\end{array}$ \\
\hline [11] & M25 to M55 & $\begin{array}{l}\text { Chicken } \\
\text { wire mesh } \\
\text { - } 1 \text { layer }\end{array}$ & Axial & $\begin{array}{l}\mathrm{d}=150 \mathrm{~mm} \\
\mathrm{~h}=900 \mathrm{~mm}\end{array}$ & $\begin{array}{l}\text { - Ferrocement is efficient for } \\
\text { strengthening concrete } \\
\text { - The lower the concrete } \\
\text { quality, the higher the } \\
\text { strength increase }\end{array}$ \\
\hline [12] & $\begin{array}{l}\mathrm{fc}=35.8 \mathrm{MPa} \\
\text { (for mortar) } \\
\mathrm{fc}=40.1 \mathrm{MPa}\end{array}$ & $\begin{array}{l}\text { WWM - } \\
11 \times 11 \mathrm{~mm} \\
\mathrm{fy}=350 \mathrm{MPa}\end{array}$ & Axial & Circular & $\begin{array}{l}\text { - Increase in strength, ductility } \\
\text { and energy absorption }\end{array}$ \\
\hline [13] & $\begin{array}{l}\mathrm{fc}=35 \mathrm{MPa} \\
\text { (for mortar) } \\
\mathrm{fc}=30 \mathrm{MPa}\end{array}$ & - & Shear & - & $\begin{array}{l}\text { - Increase shear capacity and } \\
\text { ductility } \\
\text { - Small mesh ratio increases } \\
\text { considerably load capacity } \\
\text { - Greater ratios needed for } \\
\text { ductility improvement } \\
\text { - Improved cracking behavior }\end{array}$ \\
\hline [14] & $\begin{array}{l}\mathrm{fc}=30 \mathrm{MPa} \\
\text { (for mortar) } \\
\mathrm{fc}=32 \mathrm{MPa}\end{array}$ & $\begin{array}{l}\text { Woven } \\
\text { wire mesh } \\
1 \text { layer }\end{array}$ & Shear & - & $\begin{array}{l}\text { - Ductile response of } \\
\text { strengthened columns } \\
\text { - Enhanced ductility }\end{array}$ \\
\hline
\end{tabular}

WWM: Welded wire mesh

A first requirement for strengthening beams with ferrocement is good, composite action between the existing element and the jacket, which can be obtained by different means, for instance, by surface preparation or surface keys, as reported by Paramasivam et al. [15]. A study by Shang et al. [16] has investigated both damaged and undamaged beams strengthened with ferrocement. It has shown that the behavior of the strengthened beams is similar to the unstrengthened beams, which means that the failure mode is still flexural, and the flexural strength does not increase significantly. The difference between the strengthened and unstrengthened specimens is that the stiffness and ductility are significantly improved. First crack load increases, while the width and spacing of the cracks decreases. Khan et al. [17] concluded that cast in-situ ferrocement jackets are 
more effective than precast panels used for strengthening beams because better bonding is assured when the mortar is cast in-situ. Furthermore, the reinforcement percentage, positively affects the load carrying capacity of the strengthened beam. Predamaged beams have been strengthened and tested in flexure by Paramsivam et al. [15] and Sivagurunthan et al. [18]. The results of these tests indicate that ferrocement jacketing increases both first crack strength and ultimate strength, ductility and flexural stiffness, while midspan deflection is increased. Nassif et al. [19] observed that welded wire mesh is more effective than hexagonal mesh.

Beam-column joints are often subject of heavy damages during earthquake loading, mostly due to improper design and detailing. Ravichandran et al. [20] successfully used ferrocement for strengthening of deficient beam-column joints, shown in Figure 8. The study indicated an increase both in terms of load, displacement capacity and energy absorption under cyclic loading. Li et al. [21] emphasize the importance of good connection between joint and jacket. Other improvements include the stiffness increase and damage level decrease after jacketing another key parameter for the effectiveness of ferrocement jacketing is the strength of mortar matrix. In addition, a study on a three floor reinforced concrete frame was carried out to investigate the behavior of ferrocement retrofitted joints by Ganesan et al. [22], in which it was found that the stiffness of the system greatly increases with the application of the jacket, as well as the base shear capacity. Failure mode is improved. More hair-like cracks develop in the ferrocement jacket while the concrete core is properly confined by it.

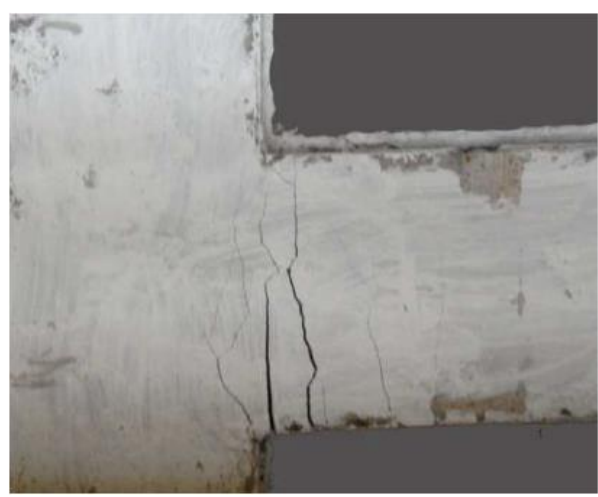

(a)

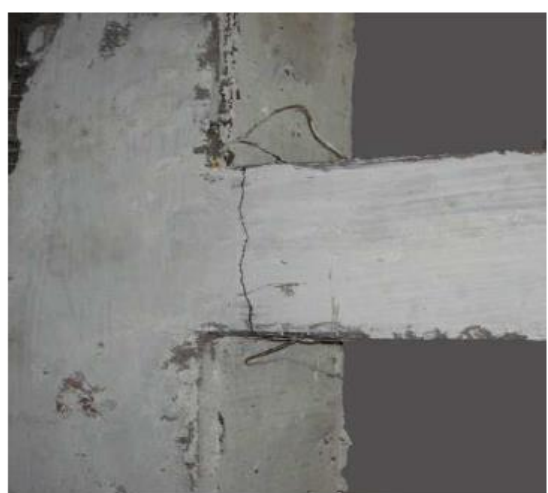

(b)

Fig. 8 Beam-column joints strengthened with ferrocement layers (courtesy of Ravichandran et al. [20])

\subsection{Strengthening Masonry Elements}

Studies on strengthening masonry columns with ferrocement jacketing have indicated that compressive strength of the column increases and crack behavior improves. According to Shahzada et al. [23] nearly-failed and then strengthened columns do not disintegrate like plain masonry columns. On the other hand, increasing the thickness of the mortar may lead to premature cracking of the jacketed columns. Other studies from Shah [24] and Shahzada et al. [25] indicate that crack spacing is significantly decreased as the wire mesh size is reduced. The strength of mortar does not affect the performance of the strengthened column, but good penetration of mortar on the wire mesh is required for a satisfactory performance. Figure 9 shows the damage pattern for unstrengthened and strengthened columns with ferrocement. 
Strengthening unreinforced masonry walls with ferrocement jackets has been attempted by several studies. As opposed to the expected outcome, Abrams et al. [26] concluded that jacketing masonry walls with ferrocement does not yield any significant improvement, either in terms of load carrying capacity, deformation capacity, ductility or mode of failure. The failure mode that was found was very similar to the failure mode of plain walls with except for the initial stage, where small cracks appeared. Once the ferrocement jacket would crack, the wall behaved as a plain unreinforced masonry wall. The potential reason for such behavior is the lack of anchors that would assure composite action between the masonry walls and the ferrocement jacket. Other studies, incorporating mechanical anchors present different results. Out-of-plane capacity of unreinforced masonry walls, investigated by Chen [27], is significantly increased after retrofitting the walls with ferrocement.

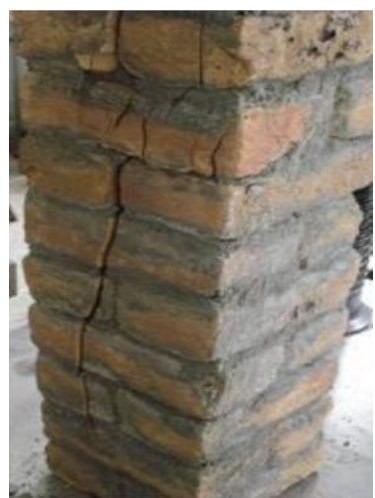

(a)

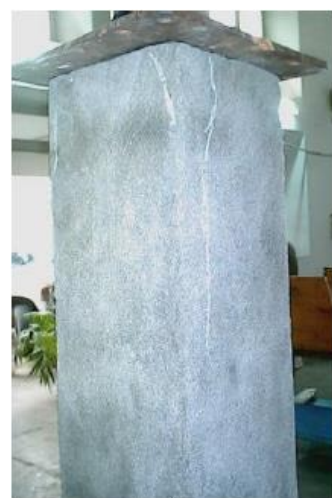

(b)

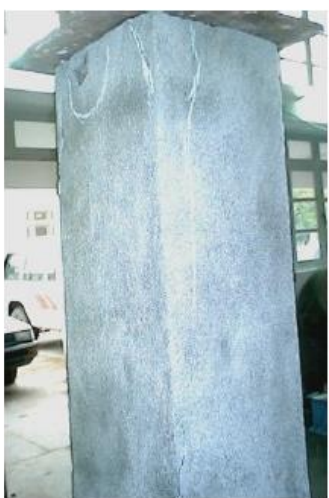

(c)

Fig. 9 (a) Unstrengthened masonry column under tested under axial load (courtesy of Shahzada et al. [23]; (b) first crack in masonry column strengthened with ferrocement jacketing (courtesy of Shah [24]); (c) multiple well-developed cracks in the ferrocement jacket (courtesy of Shah [24])

Corradi et al. [28] concluded that in-plane strength and stiffness of unreinforced masonry walls are increased after jacketing with ferrocement layers. Failure mode of ferrocement strengthened walls with anchors is improved from mixed flexural and shear behavior into purely flexural behavior, as reported by Ahmad et al. [29].This result is also supported by a test on a full scale URM structure, in the study of Ashraf et al. [30]. The unreinforced masonry structure goes from a mix behavior of compression-shear-flexure, to purely rocking failure, which is accepted as ductile failure for masonry walls. This study as well indicates increase in shear strength and stiffness of the structure, and consequently the deformation and ductility are slightly decreased. The results obtained from strengthening masonry columns are summarized in Table 2.

Reinforced concrete frames with masonry infill walls usually have a special behavior and considerably affect the overall behavior of the structure. Among the suggested strengthening methods from Turkish Code for reinforced concrete frames with masonry walls is ferrocement jacketing. On a study by Korkmaz et al. [31] on this topic, it is shown that in overall, the ferrocement jacket does increase the strength, stiffness and ductility of reinforced concrete frames with masonry infills. The infill wall is converted into a load bearing wall. From the experiment it was concluded that the thickness of the mortar is important to ensure the success of the test. In the initial stages of the experiment, a thickness of $15 \mathrm{~mm}$ was adopted, but as the first specimen was not very satisfactory, thus mortar thickness was increased to $30 \mathrm{~mm}$. 
Table 2 Summary of findings from tests on masonry columns

\begin{tabular}{|c|c|c|c|c|}
\hline $\begin{array}{l}\text { Study } \\
\text { Ref. }\end{array}$ & $\begin{array}{l}\text { Material } \\
\text { properties }\end{array}$ & Test & Specimen & Findings \\
\hline [26] & - & $\begin{array}{l}\text { Cyclic } \\
\text { test }\end{array}$ & Masonry pier & $\begin{array}{l}\text { Ferrocement strengthened wall } \\
\text { behaved similarly to plain wall. } \\
\text { The reason: lack of } \\
\text { connection/proper anchorages. }\end{array}$ \\
\hline [27] & $\begin{array}{l}\mathrm{fb}=37.8 \\
\mathrm{MPa} \\
\mathrm{fm}=24 \mathrm{MPa}\end{array}$ & $\begin{array}{l}\text { Ou-of- } \\
\text { plane } \\
\text { strength }\end{array}$ & $\begin{array}{l}\text { Masonry wall } \\
1 \times 1 \times 0.115 \mathrm{~m}\end{array}$ & $\begin{array}{l}\text { Out-of-plane load capacity is } \\
\text { greatly increased by the addition } \\
\text { of ferrocement walls, compared to } \\
\text { plain walls, that have zero out-of- } \\
\text { plane capacity. }\end{array}$ \\
\hline [23], [25] & $\mathrm{fb}=13 \mathrm{MPa}$ & Axial load & $\begin{array}{l}\text { Masonry } \\
\text { walls } \\
0.4 \times 0.5 \times 0.23 \\
\mathrm{~m}\end{array}$ & $\begin{array}{l}\text { One ferrocement layer can } \\
\text { increase strength by } 40 \% \text {. } \\
\text { Excessive mortar thickness and } \\
\text { improper curing can lead to } \\
\text { premature cracking. }\end{array}$ \\
\hline
\end{tabular}

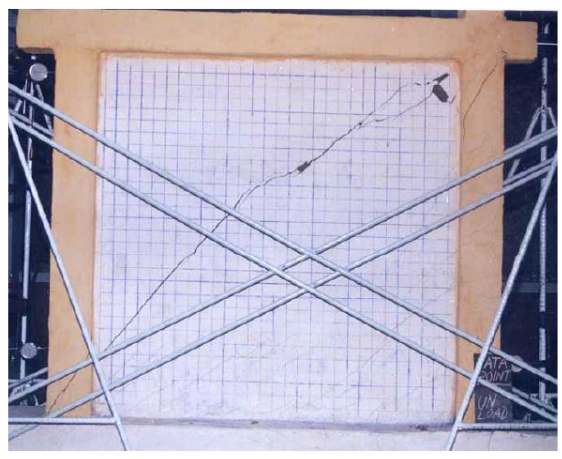

(a)

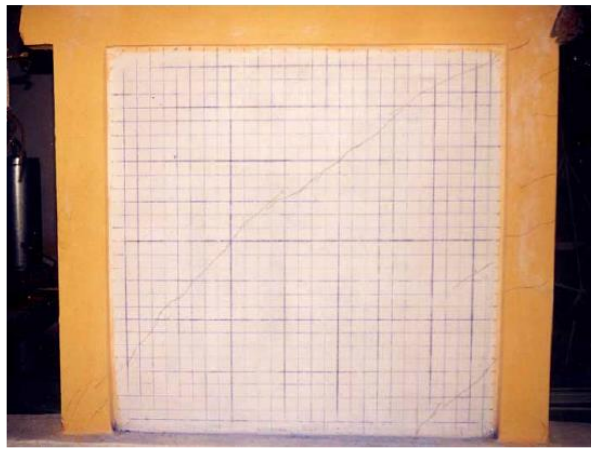

(b)

Fig. 10 (a) Unstrengthened masonry infill RC frame tested under lateral load; (b) Infill RC frame strengthened with ferrocement and tested under lateral load; (courtesy of Amanat et al. [32])

On the other hand, the technique is not appropriate for any kind of reinforced concrete frame. In the case the concrete quality is very poor, such as 8-10 MPa, the ferrocement jacketing may strengthen the infill wall more than necessary and offset the damage into the frame. In such situation, strengthening of the frame elements is needed before strengthening the infill wall. In the case of damaged reinforced concrete frame with infill walls, the findings were surprising. Amanat et al. [32] reported that not only the ferrocement overlay can help to restore the strength and stiffness of reinforced concrete frames with infill walls, but it can also exceed the capacity of the frame prior to damage. The failure mode of unstrengthened vs. strengthened infill RC frames is shown in Figure 10.

\section{Conclusions}

In this study, a review on the properties and uses of ferrocement is presented. Though ferrocement is an old material, it has seen little use until the recent decades. It is similar with reinforced concrete, in that it is composed of mortar and steel wire mesh, as opposed to steel bars and concrete, but they differ significantly in terms of properties. The strongest feature of reinforced concrete is compressive strength, while ferrocement 
has excellent tensile and flexural behavior. Conventional reinforced concrete is brittle material, while ferrocement is very ductile. On the other hand, ferrocement does not have the good durability of reinforced concrete due to the thin sections and very thin concrete covers. Conventional uses of ferrocement include mostly boats, water tanks, silos and roofing. New perspectives on the usage of ferrocement have appeared in the last three decades.

Ferrocement is an optimum low-cost material for low-rise, earthquake resistant structures. This has been proven analytically, experimentally and during earthquake events. It is also appropriate for strengthening structural elements, such as reinforced concrete beams and columns, and masonry walls and columns. The results of strengthening experiments have indicated considerable increase in strength, stiffness, ductility and improvement in cracking behavior.

In overall, the studies presented confirm the good properties of ferrocement outlined in the ACI 549R-97. Also, attempts to quantify the effect of wire mesh type and orientation on the behavior of the composite has been made. The use of ferrocement as strengthening material has not been foreseen by ACI 549R-979, but has turned out to be a very good perspective. In all cases, ferrocement greatly improves the performance of the strengthened elements, under the condition that good connection between the structural element and the ferrocement jacket is achieved. Low-rise, low-cost, earthquake resistant houses have been constructed using ferrocement, which have proven their good performance during high magnitude Chile $27^{\text {th }}$ of February, 2010 earthquake.

\section{References}

[1] ACI Committee 549. State-of-the-art report on ferrocement. American Concrete Institute, Farmington Hills, USA, 1997

[2] Arif M, Pankaj, Surendra KK. Mechanical behavior of ferrocement composites: an experimental investigation. Cement and Concrete Composites, 1999; 21: 301 - 312. http://dx.doi.org/10.1016/S0958-9465(99)00011-6

[3] Chapple P. Seismic damage, constructing structures. BIT, 2012; $14-25$.

[4] Montes JLC, Ramirez RA, Aquino TC. The experience of CIIDIR IPN in the design of ferrocement houses and public buildings in Oaxaca, Mexico. Boletin Informativo ASOCEM, 2012; Lima, Peru.

[5] Ruiz DB, Betancur DA. Behavior of ferrocement houses under cyclic loading. Revista Ingenierias Universidad de Medellin, 2009; 8: 37 - 46.

[6] Saleem MA, Ashraf M. Low cost earthquake resistant ferrocement small house. Journal of Engineering and Applied Sciences, 2008; 2: 59 - 64.

[7] Institute of Cement and Concrete of Chile. Definite solutions: Ferrocement for housing. Boletin: Hormigon del dia, 2010; 47: 5 - 7.

[8] Mourad SM, Shannag MJ. Repair and strengthening of reinforced concrete square using ferrocement jackets. Cement and Concrete Composites, 2012; 34: 288 - 294. http://dx.doi.org/10.1016/j.cemconcomp.2011.09.010

[9] Kaish ABMA, Alam MR, Jamil M, Zain MFM, Wahed MA. Improved ferrocement jacketing for restrengthening of square RC short column. Construction and Building Materials, 2012; 36:228 - 237. http://dx.doi.org/10.1016/j.conbuildmat.2012.04.083

[10]Kaish ABMA, Alam MR, Jamil M, Wahed MA. Ferrocement jacketing for restrengthening of square reinforced concrete columns under concentric compressive load. Procedia Engineering, 2013; 54:720 - 728. http://dx.doi.org/10.1016/j.proeng.2013.03.066

[11]Kondraivendhan B, Pradhan B. Effect of ferrocement confinement on behavior of concrete. Construction and Building Materials, 2009; 23: 1218 - 1222. http://dx.doi.org/10.1016/i.conbuildmat.2008.08.004 
[12]Xiong GJ, Wu XY, Li FF, Yan Z. Load carrying capacity and ductility of circular concrete columns confined by ferrocement including steel bars. Construction and Building

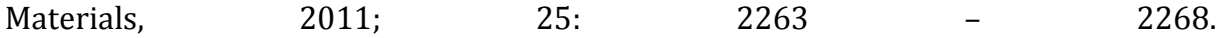
http://dx.doi.org/10.1016/i.conbuildmat.2010.11.014

[13]Kazemi MT, Morshed R. Seismic strengthening of R/C columns with ferrocement jacket. Cement and Concrete Composites, 2005; 27: $834-842$. http://dx.doi.org/10.1016/i.cemconcomp.2005.03.011

[14]Abdullah, Takiguchi K. An investigation into the behavior and strength of reinforced concrete columns strengthened with ferrocement jackets. Cement and Concrete Composites, 2003; 25: 233 - 242. http://dx.doi.org/10.1016/S0958-9465(02)000057

[15]Paramasivam P, Lim CTE, Ong KCG. Strengthening of RC beams with ferrocement laminates. Cement and Concrete Composites, 1998; 20: 53 - 65 . http://dx.doi.org/10.1016/S0958-9465(97)00068-1

[16]Shang SP, Zeng LO, Peng H. Flexural strengthening of reinforced concrete beam with ferrocement. $2^{\text {th }}$ Conference in Our World in Concrete and Structures, 2003.

[17]Khan SU, Rafeeqi SFA, Ayub T. Strengthening of RC beams in flexure using ferrocement. Iranian Journal of Science and Technology, Transactions of Civil Engineering, 2013; 37: 353 - 363.

[18]Sivagurunthan B, Vidivelli B. Strengthening of predamaged reinforced concrete beams by ferrocement plates. International Journal of Current Engineering and Technology, 2012; 2: $340-344$.

[19]Nassif HH, Najm H. Experimental and analytical investigation of ferrocementconcrete composite beams. Cement and Concrete Composites, 2004; 26: 787 - 796. http://dx.doi.org/10.1016/j.cemconcomp.2003.08.003

[20]Ravichandran K, Jeyasahar CA. Seismic retrofitting of exterior beam-column joint using ferrocement. International Journal of Engieering and Applied Sciences, 2012; 4: $35-58$.

[21] Li B, Lam ES, Wu B, Wang Y. Experimental investigation on reinforced concrete interior beam-column joints rehabilitated by ferrocement jackets. Engineering Structures, 2013; 56: 897 - 909. http://dx.doi.org/10.1016/j.engstruct.2013.05.038

[22]Ganesan N, Indira PV, Thadathil SP. Effect of ferrocement wrapping system on strength and behavior of RC frames under reversed lateral cyclic loading. Experimental Techniques, 2011; 35: 23 - 28. http://dx.doi.org/10.1111/j.17471567.2010.00617.x

[23]Shahzada K, Alam B, Javed M, Ali Z, Khan H, Shah SSA. Retrofitting of brick masonry columns by ferrocementing. International Journal of Advanced Structures and Geotechnical Engineering, 2012; 1: 50 - 54.

[24]Shah AA. Applications o ferrocement in strengthening of unreinforced masonry columns. International Journal of Geology, 2011; 5: 21 - 27.

[25]Shahzada K, . Strengthening of brick masonry walls against earthquake loading. International Journal of Advanced Structures and Geotechnical Engineering, 2012; 1: $10-14$.

[26]Abrams D, Smith T, Lynch J, Franklin S. Effectiveness of rehabilitation on seicmic behavior of masonry piers. Journal of Structural Engineering, 2007; 133: 32 - 43. http://dx.doi.org/10.1061/(ASCE)0733-9445(2007)133:1(32)

[27]Chen S. Out-of-plane behavior of masonry walls strengthened with ferrocement. Advanced Materials Research, 2011; 163 - 167: 3545 - 3550.

[28]Corradi M, Borri A, Vingoli A. Experimental evaluation of in-plane shear behavior of masonry walls retrofitted using conventional and innovative methods. Journal of the British Masonry Society, 2008; 21: 1 - 14. 
[29]Ahmad N, Ali Q, Ashraf M, Naeem A, Alam B. Seismic performance evaluation of reinforced plaster retrofitting technique for low-rise block masonry structures. International Journal of Earth Sciences and Engineering, 2012; 5: 193 - 205.

[30]Ashraf M, Khan AN, Ali Q, Shahzada K, Naseer A. Experimental behavior of full-scale URM building retrofitted with ferrocement overlay. Advanced Materials Research, 2011; 255 - 260: $319-323$.

[31]Korkmaz SZ, Kamanli M, Korkmaz HH, Donduren MS, Cogurcu MT. Experimental study on the behavior of nonductile infilled RC frames with external mesh reinforcement and plaster composites. Natural Hazards and Earth System Sciences, 2010; 10: 2305 - 2316. http://dx.doi.org/10.5194/nhess-10-2305-2010

[32]Amanat KM, Alam MMM, Alam MS. Experimental investigation of the use of ferrocement laminates for repairing masonry infilled RC frames. Journal of Civil Engineering, 2007; 35: 71-80. 